\title{
Alternative Wnt Pathways and Receptors
}

\author{
Renée van Amerongen \\ Department of Developmental Biology, Stanford University, Stanford, California 94305; Netherlands Cancer \\ Institute, Division of Molecular Oncology, Plesmanlaan 121, 1066 CX Amsterdam, The Netherlands \\ Correspondence: r.v.amerongen@nki.nl
}

In addition to activating $\beta$-catenin/TCF transcriptional complexes, Wnt proteins can elicit a variety of other responses. These are often lumped together under the denominator "alternative" or "non-canonical" Wnt signaling, but they likely comprise distinct signaling events. In this article, I discuss how the use of different ligand and receptor combinations is thought to give rise to these alternative Wnt-signaling responses. Although many of the biochemical details remain to be resolved, it is evident that alternative Wnt signaling plays important roles in regulating tissue morphogenesis during embryonic development.

$T^{\mathrm{h}}$ he very notion of an "alternative" mode of Wnt signaling implies the existence of a default response. That honor befalls the Wnt- and Frizzed/LRP-mediated stabilization of $\beta$-catenin and its concomitant association with LEF/ TCF transcription factors (historically called "canonical" Wnt signaling and hereafter referred to as Wnt/ $\beta$-catenin signaling), which remains the best understood and most studied response to Wnt ligand stimulation. There are multiple instances, however, in which Wnt proteins elicit a biological response that does not appear to involve the activation of $\beta$-catenin/ TCF complexes. For lack of a better description, these responses are often jointly referred to as "alternative" Wnt signaling.

An obvious first question, then, might be to ask how many alternative responses exist. Perhaps less obvious is the answer to this question: We don't really know. The main reason for this is the fact that $\beta$-catenin-independent signaling responses remain relatively poorly characterized at the molecular level. As a result, we lack the robust readouts that exist to probe $\mathrm{Wnt} / \beta$-catenin signaling. Fortunately, we are gaining an ever-increasing understanding of the molecular players involved in and the developmental events controlled by alternative Wnt signaling.

\section{ROLES FOR $\beta$-CATENIN-INDEPENDENT WNT SIGNALING IN DEVELOPMENT}

Before discussing the initiation and progression of alternative Wnt-signaling responses, I shall introduce some of the physiological processes that are controlled by $\beta$-catenin-independent Wnt signaling in vivo. In general, rather than affecting cell proliferation or cell fate specification, alternative Wnt signaling controls various aspects of cell migration and polarity, thereby having profound effects on tissue morphogenesis.

Editors: Roel Nusse, Xi He, and Renee van Amerongen

Additional Perspectives on Wnt Signaling available at www.cshperspectives.org

Copyright (C) 2012 Cold Spring Harbor Laboratory Press; all rights reserved; doi: 10.1101/cshperspect.a007914

Cite this article as Cold Spring Harb Perspect Biol 2012;4:a007914 
R. van Amerongen

\section{Planar Cell Polarity}

The process in which cells align themselves within the plane of a tissue is called planar cell (or tissue) polarity (PCP). Although it is observed in a wide variety of tissues, the two best-known examples are the uniform array of distally pointing hairs in the fly wing and the coordinated polarization of cochlear hair cells in the mammalian inner ear (Fig. 1A,B). However, PCP can also encompass the alignment of larger structures rather than individual cells, such as the multicellular ommatidia in the compound fly eye, and even entire hair follicles in the mammalian skin (Montcouquiol et al. 2003; Devenport and Fuchs 2008; Jenny 2010; Maung and Jenny 2011).

Although the Wnt-pathway components frizzled (fz) and dishevelled (dsh) are core PCP proteins (Fig. 1C), it should be stressed that to date there is no evidence for the involvement of a ligand in either the establishment or maintenance of PCP in the Drosophila wing and ommatidia (Chen et al. 2008). This issue has been long debated, however, and recent evidence suggests that this might not hold true for all tissues (Shimizu et al. 2011). Furthermore, Wnt proteins have been implicated in PCP in vertebrates and
A
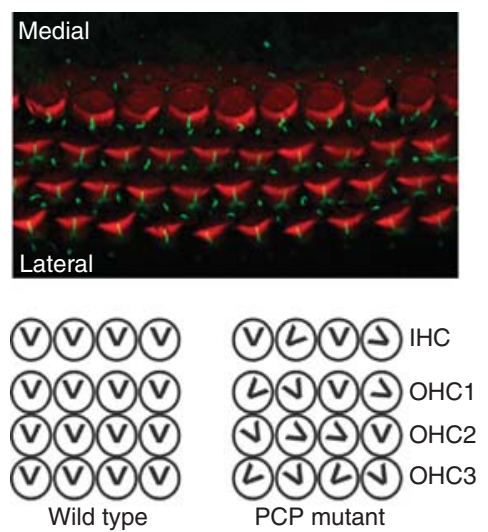

B

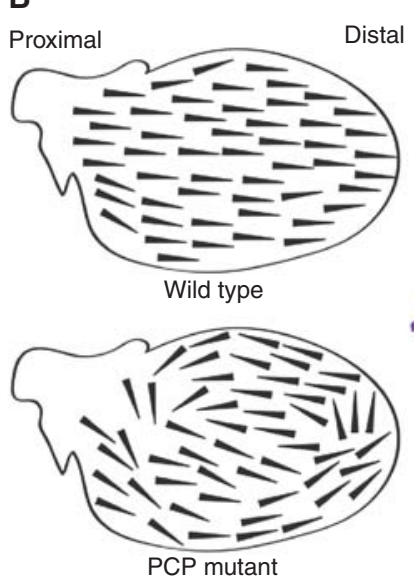

C

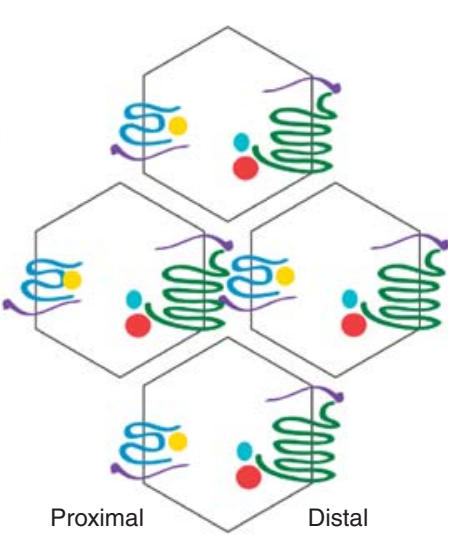

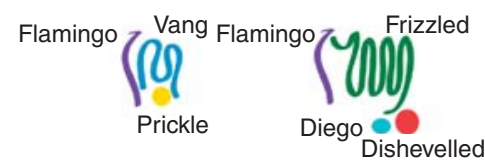

Figure 1. Planar cell polarity (PCP) as an example of alternative Wnt signaling. $(A$, top $)$ PCP in the sensory epithelium of the mammalian cochlea manifests itself in the alignment of inner ear hair cells, which carry characteristic V-shaped stereociliary bundles of actin hairs on the apical cell surface (visualized here by phalloidin staining in red; kinocilia are stained green with an antibody against acetylated tubulin). (Bottom) PCP defects are scored based on the misorientation of these sterociliary bundles on inner (IHC) and outer (OHC) hair cells in whole-mount preparations of the organ of Corti. $(B, t o p)$ In a textbook example of PCP, the surface of the fly wing is covered with a neatly organized array of hairs, all of which point toward the distal side. (Bottom) Defects in PCP are typically scored based on the misorientation of wing hairs. (C) Molecular control of PCP in the Drosophila wing. Complexes of the transmembrane proteins flamingo and vang, together with the cytoplasmic protein prickle, accumulate at the proximal end of the cell. At the distal border, flamingo and frizzled accumulate together with dishevelled and diego. Interactions between the extracellular domains of flamingo, frizzled, and vang are thought to play an important role in maintaining these complexes at opposite sides of the cell boundary (Chen et al. 2008; Wu and Mlodzik 2008). In addition, diego has been proposed to promote fz/ dsh signaling, whereas vang/pk is thought to prevent recruitment of dsh to the cell membrane, something that is a prerequisite for PCP signaling (Tree et al. 2002; Das et al. 2004; Jenny et al. 2005). 
Caenorhabditis elegans (Dabdoub et al. 2003; Dabdoub and Kelley 2005; Wu and Herman 2006; Qian et al. 2007; Yamamoto et al. 2008).

\section{Convergent Extension}

The same core players that control PCP have been shown to regulate a seemingly unrelated developmental process, called convergent extension (CE) (Keller and Danilchik 1988; Warga and Kimmel 1990; Wallingford et al. 2000). This morphogenetic event refers to the simultaneous lengthening and narrowing of a tissue as the result of directional cell intercalation. As such, CE movements control extension of the primary body axis and neural tube closure (Keller et al. 1985; Davidson and Keller 1999). For experimental reasons, CE is mostly studied in Xenopus and zebrafish, in which gastrulation defects are relatively easy to score. In addition, CE can be monitored and manipulated in Xenopus animal cap assays (Wilson et al. 1989; Hertzano et al. 2004). Both Wnts and Frizzleds (Fzds), as well as Dishevelled (Dvl) and other core PCP proteins, have been implicated in CE in amphibians, fish, and mammals (Djiane et al. 2000; Heisenberg et al. 2000; Carreira-Barbosa et al. 2003; Kilian et al. 2003; Torban et al. 2004; Moeller et al. 2006; Wang et al. 2006a; Kim et al. 2008). However, despite the fact that PCP and $\mathrm{CE}$ are often used interchangeably when discussing the role of alternative Wnt signaling, it is important to bear in mind that they are two distinct biological phenomena that are often studied in different species. Although they share the same core components, different downstream effector mechanisms are therefore prone to exist, and PCP and CE are unlikely to be controlled by completely identical signal transduction events (Fig. 2) (see also the section on Downstream Signaling Events). Future studies will have to determine how similar (or different) their underlying machineries really are.

\section{Other Developmental Consequences of Defects in Alternative Wnt Signaling}

Because the proteins previously implicated in PCP and CE are found to control multiple aspects of mammalian development, the possibility arises that these processes may underlie polarized cell movements in general. Indeed, the developmental consequences of deregulated alternative Wnt signaling are substantial and include deficits in left/right patterning (Zhang and Levin 2009; Antic et al. 2010; Song et al. 2010), branching morphogenesis (Shabani et al. 2008; Karner et al. 2009; Yates et al. 2010), cardiac outflow tract formation (Hamblet et al. 2002; Phillips et al. 2005; Etheridge et al. 2008), intestinal elongation (Cervantes et al. 2009; Yamada et al. 2010), limb outgrowth (Yamaguchi et al. 1999; Afzal et al. 2000; van Bokhoven et al. 2000; Schwarzer et al. 2009; Person et al. 2010; Gao et al. 2011), and neural tube closure (Kibar et al. 2001, 2011; Montcouquiol et al. 2003; Seo et al. 2011).

Of note, not all $\beta$-catenin-independent responses to Wnt-ligand stimulation have been definitively linked to PCP/CE. However, recent reports showing the hitherto unknown involvement of PCP proteins other than Fzd and Dvl in Wnt-mediated axon guidance and differentiation underscore that this may simply be a matter of time (Shafer et al. 2011; Shimizu et al. 2011).

\section{ALTERNATIVE WNT-SIGNALING MECHANISMS}

Initiation of the Wnt-signaling response is first and foremost decided at the level of ligand and receptor binding. In all animal species, however, both Wnts and Fzds belong to large, multigene families, complicating a comprehensive analysis of their signaling activities. Further diversification of the signaling response comes from the use of different (co-)receptors and cytoplasmic effectors. With this in mind, future studies have to take into account that the outcome of a given Wnt-signaling event is determined by the ligand and receptor context and the developmental history of the receiving cell.

At the tissue level, the response is ultimately controlled by a "Wnt code" or "Wnt landscape" that integrates the complex expression patterns and different signaling inputs of multiple Wnt ligands and (ant)agonists (Gleason et al. 2006; Guder et al. 2006; Green et al. 2008; Zinovyeva et al. 2008; van Amerongen and Nusse 2009; Janssen et al. 2010; Fossat et al. 2011). 


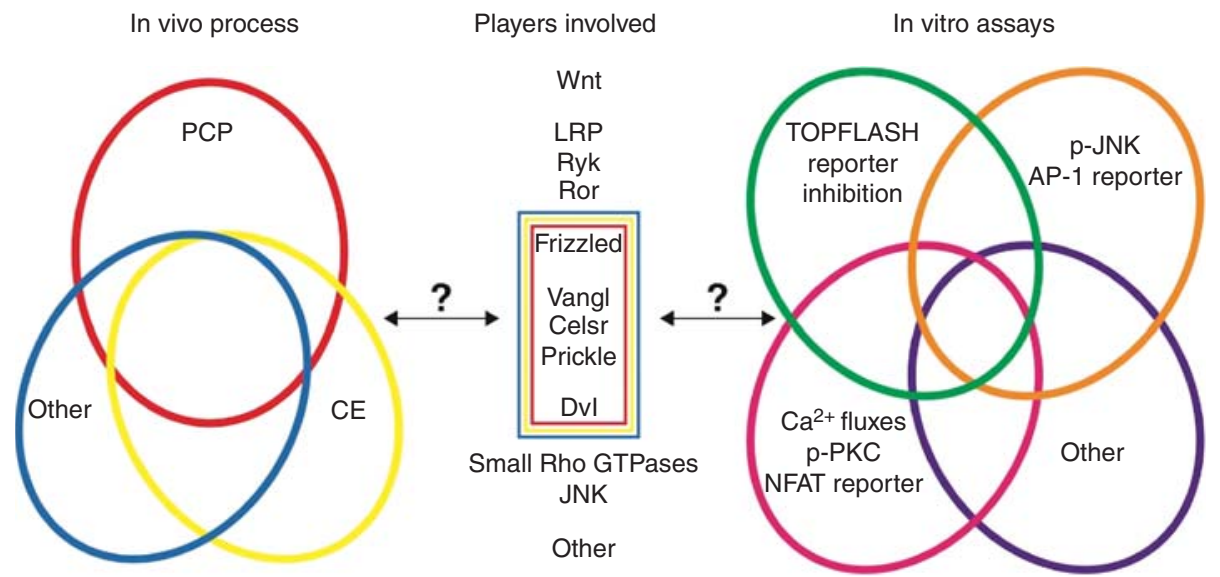

Figure 2. Knowledge gaps. In the absence of robust and quantitative readouts, it has remained difficult to dissect the biological processes (left) in which alternative Wnt-signaling components (center) play a role in distinct signal transduction events (right). For instance, despite the fact that multiple Wnt-pathway components show a genetic interaction with core PCP/CE proteins (boxed in the center), it remains unknown how Wnts and their (co-)receptors are tied to the core PCP/CE machinery at the biochemical level. As an example, the core PCP/CE protein vang/Vangl2 plays a central role in tissue morphogenesis. Animals deficient for vang/Vangl2 display severe defects in PCP (red ellipse; e.g., cochlear hair cell orientation) and CE (yellow ellipse; e.g., neural tube closure), as well as in developmental processes that have not (yet) been definitively linked to either PCP or CE (blue ellipse; e.g., lung branching morphogenesis). A genetic interaction with Vangl2 has been shown for both Wnt5a and Ror2, and Wnt5a/Ror2 has been reported to phosphorylate Vangl2 in the murine limb bud (Qian et al. 2007; Yamamoto et al. 2008; Gao et al. 2011). The most robust assay to monitor Wnt5a/Ror2 signaling in vitro is inhibition of the Wnt/ $\beta$-catenin-responsive TOPFLASH luciferase reporter (green ellipse). However, Wnt5a and Ror2 have also been reported to activate JNK and AP-1 in mammalian cell culture experiments (orange ellipse). It is unknown how far these two responses overlap and whether they involve Vangl2. Conversely, it is unknown whether either Wnt5a or Ror2 plays a direct role in the diverse tissue-morphogenetic events in which Vangl2 has been implicated.

\section{Use of Alternative Wnt Ligands}

From the moment it became clear that Wnt proteins were members of an evolutionarily conserved family of signaling molecules (Baker 1987; Rijsewijk et al. 1987), attempts were made to classify them into groups with distinct properties. Two assays that were regularly used for this were the morphological transformation of C57MG cells and axis duplication in Xenopus embryos. The former scores the ability of individual Wnt proteins to change these cells from a cuboidal to a spindle-like cell shape (Jue et al. 1992), whereas the latter makes use of the fact that ectopic Wnt/ $\beta$-catenin signaling on the ventral side of the early embryo will induce formation of a secondary body axis (McMahon and Moon 1989; Sokol et al. 1991). Although no one has ever reported an exhaustive side-by- side comparison of the behavior of all 19 mammalian Wnt genes in both assays, it was clear that the capacity of some Wnt proteins (e.g., Wnt3a), but not others (e.g., Wnt5a), to induce transformation and cause an increase in the cellular levels of $\beta$-catenin in C57MG cells (Wong et al. 1994; Shimizu et al. 1997) corresponded to their ability to induce axis duplication in Xenopus (Du et al. 1995). The transforming Wnts became known as "canonical" and were assumed to activate $\beta$-catenin/TCF signaling. In contrast, the non-transforming or "non-canonical" Wnts were thought to use alternative signaling mechanisms. Since then, Wnt3a and Wnt5a have become the prototypes for either class.

Although valuable, these assays do have some drawbacks. For instance, the C57MG morphological transformation assay is not quantifiable and therefore difficult to interpret, especially for 
weak transforming genes (e.g., Wnt6, Wnt7B), which might explain why they have an effect in some studies, but not others (Wong et al. 1994; Shimizu et al. 1997). More importantly, the strict subdivision into canonical and noncanonical Wnts is a vast oversimplification, and an important caveat of these early classification attempts is the fact that they overlooked the importance of receptor context.

Instead of inducing axis duplication upon injection into early Xenopus embryos, exogenous Wnt5a does not affect development until after the onset of gastrulation, ultimately resulting in complex head and tail malformations. In addition, Wnt5a blocks the elongation of blastula cap explants, first suggesting a role in controlling the CE movements associated with gastrulation (Moon et al. 1993). However, Wnt5a was subsequently shown to be able to induce an ectopic axis when it was coinjected with Fz5 ( $\mathrm{He}$ et al. 1997). Likewise, Wnt5a was found to activate $\beta$-catenin/TCF signaling when it was added to 293 cells overexpressing a combination of Fzd4/LRP5 receptors (Mikels and Nusse 2006). Furthermore, when Wnt5a or Wnt11 was fused to Fzd5, both were able to induce a secondary axis in Xenopus embryos-something that is never observed for either Wnt alone (Holmen et al. 2002).

Importantly, in vivo studies support the idea that individual Wnt proteins can have different functions depending on the time and place of their activity. Formation of the primary body axis in Xenopus depends on Wnt/ $\beta$-catenin signaling on the dorsal side of the fertilized oocyte. Quite surprisingly, maternal Wnt5a and Wnt11, at the time generally considered noncanonical Wnt proteins, were shown to be required for this process (Tao et al. 2005; Cha et al. 2008). Even more remarkable was the discovery that Wnt5a and Wnt11 function together in a multimeric complex to induce $\mathrm{Wnt} / \beta$-catenin signaling during primary axis formation (Cha et al. 2009). Yet the same proteins clearly control $\beta$-catenin-independent gastrulation events at subsequent stages of development (Cha et al. 2008), as illustrated by the fact that both the Wnt11/Silberblick and Wnt5a/Pipetail zebrafish mutants display defects in convergent ex- tension movements (Heisenberg et al. 2000; Kilian et al. 2003).

Thus, the same Wnt proteins can have both $\beta$-catenin-dependent and -independent functions depending on the cellular context, suggesting that any definitive conclusions regarding their signaling activity should be made on a case-by-case basis. That being said, it is a fact that some Wnts are less often associated with $\beta$-catenin/TCF signaling than others. Precisely what controls ligand and receptor affinity or intrinsic differences in signaling capacity remains to be determined.

\section{Alternative Use of Frizzled and Dishevelled}

Genetic screens in Drosophila provide a powerful tool for dissecting signaling pathways. Using epistasis experiments, it was shown that wingless ( $w g /$ Wnt) functioned upstream of a frizzled $(f z /$ Fzd) transmembrane receptor and used $d i-$ shevelled (dsh/Dvl) and zeste-white (zw/GSK3) to ultimately signal through armadillo $(\mathrm{arm} / \beta$ catenin) and pangolin (pan/TCF), thereby providing a blueprint of the now well-known Wnt/ $\beta$-catenin pathway (Siegfried et al. 1992, 1994; Noordermeer et al. 1994; Bhanot et al. 1996; van de Wetering et al. 1997). In addition to controlling segment polarity, however, both $f z$ and $d s h$, but not arm, were found to be required for the establishment of PCP in collaboration with a completely distinct set of signaling partners (Vinson et al. 1989; Wong and Adler 1993; Axelrod et al. 1998). These include flamingo, vang, and prickle (Celsr1/2/3, Vangl1/2, and Prickle $1 / 2 / 3$ in vertebrates) (see also Fig. 1C) (see section on Core PCP/CE Proteins).

\section{Frizzled}

Similar to the situation observed for Wnts, not all Frizzled proteins are equal. The mammalian genome encodes ten Frizzled proteins. Of these only Fzd3 and Fzd6 have been implicated in PCP signaling so far (Guo et al. 2004; Montcouquiol et al. 2006; Wang et al. 2006b, 2010). Of the four frizzled receptors present in Drosophila, $f z$ and $f z 2$ function redundantly in transmitting the $w g / a r m$ signal (Bhat 1998; Kennerdell and 
R. van Amerongen

Carthew 1998; Bhanot et al. 1999). However, $f z 2$ has a higher affinity for $w g$, and only $f z$ is required for PCP signaling (Rulifson et al. 2000) or capable of recruiting $d s h$ to the cell membrane (Axelrod et al. 1998).

An intrinsic difference between the two receptors was shown to reside in their cytoplasmic tails, which affected both their subcellular localization and their capacity to activate either the Wnt/ $\beta$-catenin or the PCP pathway (Boutros et al. 2000; Wu et al. 2004). Despite the fact that no Wnt protein appears to be required for PCP signaling in the Drosophila wing, the $f z$ cysteine-rich domain (CRD), which constitutes the $w g$ binding site, is indispensable and might interact with flamingo/vang complexes on adjacent cells ( Wu and Herman 2006; Wu and Mlodzik 2008).

Again, however, the involvement in either $\mathrm{Wnt} / \beta$-catenin or alternative signaling responses is not black and white. Even though certain Fzds may be more prone to participate in one pathway than the other, a single Fzd receptor can have multiple signaling activities. For instance, Fzd7 has been well documented to control $\beta$-catenin-dependent as well as -independent developmental events in Xenopus (Medina et al. 2000; Sumanas et al. 2000; Abu-Elmagd et al. 2006). In addition, overexpression of Fzd7 was shown to inhibit convergent extension movements through Dvl (Djiane et al. 2000), whereas loss of Fzd7 was shown to disrupt the separation of mesodermal and ectodermal tissues in a Dvl-independent manner (Medina et al. 2000; Winklbauer et al. 2001). Similarly, Fzd 2 has been linked to both $\beta$-catenin-dependent as well as -independent responses in mammalian cells (Liu et al. 1999; Ma and Wang 2007; Verkaar et al. 2009; Sato et al. 2010). This shows that, similar to Wnts, individual Fzds can signal through multiple independent branches (see below), only some of which may require Dvl.

\section{Dishevelled}

The first indication for a dual signaling role for Dishevelled (Dvl) came from the identification of the Drosophila $d s h^{1}$ allele, which causes defects in PCP, but not in Wnt/ $\beta$-catenin signal- ing (Adler 1992). Since then, much effort has been made to map the domains that are required for the different signaling activities of Dvl. The protein contains three well-conserved domains: an amino-terminal DIX domain, a central PDZ domain, and a carboxy-terminal DEP domain. Of these, the DIX domain is critically required for inducing Wnt/ $\beta$-catenin signaling. It has been shown to mediate dynamic polymerization, resulting in the recruitment of Fzd/LRP complexes into large signalosomes (Bilic et al. 2007; Schwarz-Romond et al. 2007a,b; Fiedler et al. 2011). Deletion of the DIX domain renders Dvl functionally inactive in a Wnt/ $\beta$-cateninresponsive TOPFLASH reporter assay as well as in Xenopus axis duplication experiments. Conversely, the PDZ and DEP domains are largely dispensable for axis duplication (Rothbacher et al. 2000). Instead, deletion mutants lacking the DEP domain are defective in disrupting CE movements (Wallingford et al. 2000).

The observation that wild-type $d s h$ was recruited to the plasma membrane by $f z$ (the receptor involved in PCP signaling), but not by $f z 2$ and $w g$ (the ligand/receptor combination that controls $w g / a r m$ signaling), in Xenopus animal cap cells suggested that membrane localization was critical for the role of $d s h$ in establishing PCP/CE (Axelrod et al. 1998). In support of this, the mutant $d s h$ protein encoded by the $d s h^{1}$ allele was found to contain a $\mathrm{K} \rightarrow \mathrm{M}$ transition mutation in the DEP domain and had lost its capacity to be recruited to the cell membrane.

These observations were elegantly confirmed in the mouse, using an allelic series of BAC transgenes (Wang et al. 2006a). The mammalian genome encodes three $D v l$ homologs, and mice deficient for both Dvl1 and Dvl2 display severe neural tube closure defects as well as cochlear hair cell orientation defects, similar to mice that carry a mutated version of the core PCP gene Vangl2 (Kibar et al. 2001; Hamblet et al. 2002; Wang et al. 2005). The neural tube closure defects observed in the $D v l 1^{-/-} ; D v l 2^{-/-}$mutants could be rescued by either a $D v l 2$ or a $D v l 2 \Delta D I X$, but not by a Dvl2 $\triangle D E P$ BAC transgene or by a $D v l 2$ BAC transgene carrying a single point mutation identical to that observed in the Drosophila $d s h^{1}$ allele (Wang et al. 2006a). 
Summarizing, the amino-terminal DIX domain of Dvl is dispensable, whereas its carboxyterminal DEP domain is required for $\mathrm{PCP} / \mathrm{CE}$ signaling. The opposite holds true for $\mathrm{Wnt} / \beta$ catenin signaling. In addition to differences in subcellular localization, the different pools of Dvl also appear to use different downstream effectors to activate the different branches of the Wnt pathway (see below).

\section{Alternative Receptors}

The interaction with Wnt ligands is mediated by the Fzd CRD domain. This same domain, which is also used by the extracellular antagonists of the secreted Frizzled-related protein (SFRP) family, was found to be present in the otherwise completely unrelated tyrosine kinase receptors Ror1 and Ror2 (Saldanha et al. 1998). A different Wnt binding domain, used by the extracellular Wnt-inhibitory factor (WIF), resides in the extracellular domain of the tyrosine kinase-related receptor Ryk (Yoshikawa et al. 2003; Inoue et al. 2004; Lu et al. 2004). Since then, both Ryk and Ror have been shown to be bona fide Wnt-pathway components that have been linked to both $\beta$-catenin-dependent and -independent Wnt-signaling events.

\section{Ror}

The single-pass transmembrane proteins of the Ror family are evolutionarily conserved across vertebrate and invertebrate species, including Drosophila, C. elegans, Xenopus, mice, and humans. The genomes of most species harbor two homologs. Studies performed in mammals to date have focused on the role of Ror2, but both Ror1 and Ror2 have been shown to mediate alternative Wnt signaling (Paganoni et al. 2010), although at present the experimental data support a role for Ror1 as a pseudokinase (Gentile et al. 2011). The fact that Ror 1 as well as Ror 2 can bind Wnt ligands directly (Oishi et al. 2003; Mikels and Nusse 2006; Fukuda et al. 2008; Liu et al. 2008) suggests that both can function as bona fide Wnt receptors. Indeed, Ror2 has been shown to interact with multiple Wnt proteins (Billiard et al. 2005; Mikels and Nusse 2006; Winkel et al. 2008).
Ror2-deficient mice present, among others, with craniofacial abnormalities and shortened limbs. Their external appearance somewhat resembles that of Wnt5a-null mice, suggesting that Wnt5a and Ror2 might have a similar function during embryonic development (Oishi et al. 1999; Yamaguchi et al. 1999; Schwabe et al. 2004). Indeed, Ror2 has since been shown to transmit a Wnt5a signal that results in inhibition of the Wnt/ $\beta$-catenin signaling response ( $\mathrm{Mi}$ kels and Nusse 2006; Mikels et al. 2009). One of the earliest indications of the existence of such an inhibitory branch of the pathway was the observation that Xenopus axis duplication induced by XWnt 1 could be inhibited by XWnt5a (Torres et al. 1996). Since then, Wnt5a has been shown to counteract Wnt/ $\beta$-catenin signaling in a broad range of cells and tissues (MacLeod et al. 2007; Nemeth et al. 2007; Roarty et al. 2009).

One possible mechanism by means of which Ror (or Fzd proteins for that matter) can affect Wnt signaling is by the competition for and sequestration of other Wnt ligands. This mechanism has been shown to exist for the Ror homo$\log$ cam-1 in C. elegans (Green et al. 2007). However, the Wnt5a/Ror2-mediated inhibition of Wnt $/ \beta$-catenin signaling was shown to require an intact tyrosine kinase domain (Liu et al. 2008; Mikels et al. 2009), suggesting an active signaling function. In contrast, Ror2 has also been reported to enhance $\mathrm{Wnt} / \beta$-catenin signaling as a coreceptor together with Fzd, independent from its intracellular, carboxy-terminal domain (Li et al. 2008), suggesting that Ror may have both kinase-dependent and -independent functions. The final verdict is also still out on whether Ror 2 mainly functions alone or in concert with other receptors (Mikels and Nusse 2006; Li et al. 2008; Yamamoto et al. 2008; Nishita et al. 2010; Sato et al. 2010). Studies that have analyzed ligand/receptor complex formation have mostly depended on protein overexpression, and as such, it is unknown to what extent these complexes exist at the physiological level. Furthermore, despite the binding partners and potential effectors that have been reported for Ror2, the precise molecular makeup of the Ror2 signaling cascade remains unknown (Matsuda et al. 2003; Sammar et al. 2004, 2009; Liu 
et al. 2007; Winkel et al. 2008; van Wijk et al. 2009; Feike et al. 2010; Witte et al. 2010). Wnt5a/Ror2-mediated inhibition of Wnt/ $\beta$ catenin signaling does not appear to involve NFAT, CamKII, or calcium fluxes (Topol et al. 2003; Mikels and Nusse 2006). Although Wnt5a has been shown to induce the expression of the E3 ubiquitin ligase Siah2 in a human colon adenocarcinoma cell line, resulting in the degradation of $\beta$-catenin (Topol et al. 2003), other data suggest that the Wnt5a/Ror2-mediated inhibition of Wnt $\beta$-catenin signaling occurs downstream from $\beta$-catenin nuclear entry (Verkaar et al. 2010). In agreement with the latter, we found no evidence of a transcriptional response following stimulation of Ror2-expressing 293 cells with purified Wnt5a, even though the Wnt3a-mediated induction of Axin 2 expression was prevented ( $\mathrm{R}$ van Amerongen and R Nusse, unpubl.). Of note, Wnt5a/Ror2 signaling has also been reported to inhibit convergent extension movements through the activation of JNK/ AP-1 (Oishi et al. 2003). Similar to Fzd, therefore, Ror proteins might elicit multiple, independent signaling responses.

Interestingly, a novel Ror1/Ror2 doubleknockout mouse model was recently reported to resemble the Wnt5a-null phenotype to a larger extent than existing models. Yet, in mouse embryo fibroblasts, the combined loss of Ror1 and Ror2 was shown to solely affect the phosphorylation of Dvl, but not the phosphorylation of c-Jun or the Wnt5a-mediated inhibition of Wnt/ $\beta$-catenin signaling (Ho et al. 2012). Thus, to what extent all of the aforementioned signaling activities of Wnt5a and Ror 2 play a role under physiological conditions remains to be determined. In either case, it appears that Wnt5a/ Ror signaling controls complex cell movements during embryonic development.

\section{Ryk}

Ryk transmembrane receptors are also conserved across vertebrate and invertebrate species. Mammalian Ryk is critically required for axon guidance and neurite outgrowth in response to multiple Wnt ligands ( Lu et al. 2004; Keeble et al. 2006). It was shown to bind both
Fzd and Dvl and to be essential for Wnt/ $\beta$-catenin signaling (Lu et al. 2004; Berndt et al. 2011). Similar to Fzd and Ror, Ryk can have different functions depending on the cellular context. For instance, the fly homologs derailed 1 and derailed2 play opposing roles in Wnt5a signaling during development of the Drosophila olfactory system (Sakurai et al. 2009).

Mammalian Ryk, as well as its C. elegans homolog lin-18, are catalytically inactive, suggesting a coreceptor function. Indeed, although the extracellular WIF domain of $l i n-18$ and $d e$ railed was required, the intracellular atypical kinase domain was found to be largely dispensable for their function (Inoue et al. 2004; Taillebourg et al. 2005). Although Ryk has mostly been studied in a neurobiological context, it was also shown to regulate gastrulation movements. In Xenopus, it was found to cooperate with Fzd7 and Wnt11 during CE (Kim et al. 2008), whereas in zebrafish, it was shown to control directional cell movements in response to Wnt5b (Lin et al. 2010). Similar to Ror1 and Ror2, at present the signaling mechanism downstream from Ryk remains incompletely understood. Interestingly, Ryk was shown to undergo cleavage, after which the carboxy-terminal fragment translocated to the nucleus in response to Wnt3 stimulation. This processing appears to be essential for the function of Ryk in controlling the differentiation of neuronal progenitor cells (Lyu et al. 2008, 2009). Ryk signaling during axon guidance in Drosophila was shown to require Src kinases (Wouda et al. 2008). However, at present there is no evidence that the Src-mediated signaling events involve Ryk cleavage.

Taken together, multiple independent responses are likely to exist downstream from ligand and receptor binding for both Frizzled and non-Frizzled receptors. Future studies will have to be aimed at understanding how specificity is achieved in light of such dynamic interactions.

\section{Downstream Signaling Events}

Most alternative Wnt-signaling responses remain ill characterized at the molecular level. The main reason for this stems from the fact 
that it has proven difficult to find a reliable experimental system in which to study alternative Wnt-signal transduction events to begin with, because complex developmental and tissue morphogenetic processes such as PCP and CE are not easily translated to a tissue culture dish (Endo et al. 2012). Molecular analyses have been further complicated by the fact that alternative Wnt signaling often leads to cytoskeletal and migratory changes, rather than a transcriptional response, resulting in the lack of specific and easily quantifiable in vitro readouts, analogous to the TOPFLASH reporter assay for $\mathrm{Wnt} / \beta$ catenin signaling.

Unlike $\beta$-catenin/TCF, many of the implicated downstream components (e.g., small Rho GTPases, JNK/AP-1, $\mathrm{Ca}^{2+} / \mathrm{NFAT}$ ) are not exclusive to alternative Wnt signaling and instead play a role in a vast array of cellular processes. Furthermore, in contrast to later-generation TOPFLASH constructs, existing luciferase reporters for monitoring AP-1 and NFAT signaling, for instance, show low-amplitude responses following stimulation with Wnt ligands, and it is probably safe to say that they have cost many a researcher a headache. The fact that many of these readouts are not as robust as the typical TOPFLASH reporter assay has surely contributed to some disagreement as to whether the measured responses are "real," and at present there is no consensus in the field that these reporters truly reflect alternative Wnt signaling.

\section{Core PCP/CE Proteins}

PCP is established by the asymmetric distribution of the so-called core PCP proteins at the cell membrane (Fig. 1C) (for review, see Bayly and Axelrod 2011; Goodrich and Strutt 2011; Gray et al. 2011). In cells of the fly wing, flamingo/ vang/prickle complexes accumulate on the proximal side of the cell, whereas complexes of flamingo/fz/dsh/diego localize to the distal side. The asymmetric localization of Fzd, Vangl, and Prickle is also observed in cochlear hair and support cells, suggesting that a comparable, although not identical, mechanism operates in mammals (Montcouquiol et al. 2006; Deans et al. 2007).
These same proteins have also been shown to mediate CE movements in frogs and fish (Djiane et al. 2000; Wallingford and Harland 2001; Darken et al. 2002; Veeman et al. 2003) and/or to control neural tube closure in mice (Curtin et al. 2003; Wang et al. 2006a; Torban et al. 2008).

One interesting characteristic is that both gain- and loss-of-function mutants for core $\mathrm{PCP} / \mathrm{CE}$ proteins display typical (albeit not identical) $\mathrm{PCP} / \mathrm{CE}$ phenotypes, suggesting that it is the correct gradient and not the absence or presence of signaling per se that is required for proper PCP/CE (Krasnow and Adler 1994; Djiane et al. 2000; Darken et al. 2002).

\section{PCP/CE Effectors}

Precisely how the core PCP/CE machinery connects to its downstream effectors remains unknown (Fig. 2). The first insight into the PCP signaling cascade came from Drosophila. Flies deficient for rhoA (a small Rho GTPase) and jun (an AP-1 transcription factor) presented with typical PCP defects in the eye and the wing (Kockel et al. 1997; Strutt et al. 1997; Weber et al. 2000). These and other genes, namely, hep (MKK7), bsk (JNK), and the small Rho GTPase rac, but not $c d c 42$, were also mapped into the PCP pathway in genetic epistasis experiments, based on the ability of their loss-offunction mutants to rescue the PCP defects induced by overexpression of either $f z$ or $d s h$ (Strutt et al. 1997; Boutros et al. 1998).

Other genes shown to be involved in Drosophila PCP signaling downstream from $f z$ and $d s h$ are inturned, fuzzy, and multiple wing hairs, which together appear to be responsible for restricting wing hair formation to the distal side of the cell (Adler 1992; Lee and Adler 2002). However, these effectors only control PCP in the wing and not in the ommatidia. Conversely, nemo was found to be required for PCP in the fly eye, but not the wing (Choi and Benzer 1994).

The vertebrate orthologs of inturned and fuzzy are required for ciliogenesis. As a result of aberrant cilia formation, both mice and frogs deficient for Inturned or Fuzzy have defects in Hedgehog signaling (Park et al. 2006; Gray et al. 2009; Zeng et al. 2010). However, unlike the loss 
of core PCP proteins such as Vang12, loss of Inturned or Fuzzy does not result in clear CE defects. Moreover, unlike Wnt5a or Ror2, neither Inturned nor Fuzzy shows a genetic interaction with Vangl2 in neural tube closure (Heydeck and Liu 2011). In contrast, the vertebrate ortholog of nemo, Nemo like kinase (NLK), genetically interacts with Wnt11 in CE during zebrafish development (Thorpe and Moon 2004). Together, these findings not only underscore that important differences may exist between the signal transduction events that control PCP and those that regulate CE, but also that even within the same species, the effectors that function downstream from the core PCP/CE protein complexes are likely to be tissue specific.

\section{Rho, Rac, and Cdc42 in Vertebrates}

The small Rho GTPases Rho, Rac, and Cdc42 have all been implicated in alternative Wnt-signal transduction in vertebrates, but their functions appear to be divergent. Evidence for the involvement of Cdc42 comes from the observation that exogenous Cdc42 affects Xenopus CE movements and the demonstration that Cdc42 is activated downstream of Wnt, Fzd, and PKC (Djiane et al. 2000; Choi and Han 2002; PenzoMendez et al. 2003). Both endogenous Rho and Rac were shown to be required for CE movements during gastrulation in the frog. In addition, the overexpression of Dvl1 and Dvl2, as well as of Fzd1 and Fzd7 but not Fzd2 or Fzd5, resulted in the activation of Rho and Rac, but not Cdc42, in 293T cells (Habas et al. 2001, 2003).

Although both Rho and Rac can activate JNK (Li et al. 1999; Moriguchi et al. 1999; Habas et al. 2001, 2003; Marinissen et al. 2004; Kim and Han 2005; Rosso et al. 2005), it has been suggested that Dvl activates two separate branches in mammalian cells. The first results in the activation of Rho, but not JNK, and requires full-length Dvl, whereas the second results in the activation of Rac and JNK and requires only the Dvl DEP domain (Habas et al. 2003). The Dvl-mediated activation of Rho was, in fact, shown to actively repress the activation of Rac during the directional migration of neural crest cells in developing zebrafish embryos (Matthews et al. 2008).

\section{JNK and AP-1 in Vertebrates}

Many experiments in amphibians, mice, and mammalian cell lines have placed JNK and AP1 signaling downstream from a Wnt-signaling cascade. For instance, in Xenopus animal cap explants, the expression of dominant-negative JNK or its activator MKK7 rescued CE movements that had been blocked by exogenous Wnt5a (Yamanaka et al. 2002). Likewise, in mice deficient for Wnt9B, which develop cystic kidneys, the levels of activated JNK2 were found to be significantly decreased (Karner et al. 2009).

Wnt as well as Dvl proteins have also been shown to activate JNK in mammalian NIH3T3 and 293T cells (Boutros et al. 1998; Li et al. 1999; Habas et al. 2003). In addition, both Wnt and Dvl can activate AP-1 transcriptional complexes, causing AP-1 luciferase reporters to be used as a surrogate readout to monitor alternative Wnt-signaling responses ( $\mathrm{Li}$ et al. 1999; Tufan et al. 2002; Yamanaka et al. 2002; Le Floch et al. 2005). A more specific and robust assay was recently described in the form of a luciferase reporter based on an ATF2 response element (Ohkawara and Niehrs 2011). This reporter was used in Xenopus embryos to monitor the effects of both gains and losses of Wnts, their receptors, and various intracellular mediators, including JNK. At present it remains unknown, however, whether this reporter can be used to monitor alternative Wnt-signaling responses in other species as well.

\section{Other Effectors: G-Proteins, $\mathrm{Ca}^{2+}$, and NFAT}

Not all alternative Wnt-signaling events have been linked to PCP and/or CE processes, and this article would not be complete without discussing them.

Frizzled proteins have officially been classified as a distinct class within the superfamily of G-protein-coupled receptors (GPCRs), although they lack certain features that are well conserved in other, conventional GPCRs (Schulte 2010).

It should be noted that, to date, controversy remains in the field regarding the requirement of G-proteins for Wnt-signal transduction, 
Alternative Wnt Pathways and Receptors

despite the fact that they have been implicated in both Wnt/ $\beta$-catenin and alternative signaling responses. For instance, RNAi-mediated depletion of $\mathrm{G} \alpha_{o}$ and $\mathrm{G} \alpha_{\mathrm{q}}$ or treatment with the G-protein inhibitor pertussis toxin (PTX) was reported to prevent the Wnt3a-mediated increase in cytosolic $\beta$-catenin levels in mammalian cells (Liu et al. 2005), whereas in Drosophila, $\mathrm{G}_{\mathrm{o}}$ hypomorphic clones showed compromised expression of $w g$ target genes (Katanaev et al. 2005). Until G-proteins are shown to be directly required for transmitting Wnt signals by using a genetic knockout approach in mice, the GPCR nature of Fzds will likely remain contested.

Signaling through GPCRs generally results in the activation of heterotrimeric G-proteins, phospholipase $\mathrm{C}$, and $\mathrm{Ca}^{2+}$ fluxes. The first evidence for the existence of a Wnt $/ \mathrm{Ca}^{2+}$ pathway came from experiments in zebrafish, where the injection of ectopic Wnt5a and Fzd2, but not Wnt 8 or Fzd1, was shown to cause an increase in the frequency of intracellular $\mathrm{Ca}^{2+}$ transients (Slusarski et al. 1997a,b). Calcium fluxes control the activity of multiple intracellular proteins, including PKC, CamKII, and calcineurin, and, indeed, all of these have been implicated in alternative Wnt signaling. For instance, Wnt5a and Fzd2 were also shown to promote the translocation of PKC from the cytoplasm to the cell membrane (Sheldahl et al. 1999), whereas Wnt5a and Wnt 11 were shown to activate CamKII (Kuhl et al. 2000). All of these activities could be inhibited by pertussis toxin (PTX), as could the aforementioned effect of Fzd7 on tissue separation in Xenopus (Winklbauer et al. 2001), suggesting the involvement of G-proteins.

In Xenopus animal cap explants, Wnt5a and Fzd2 were shown to promote the nuclear translocation of NFAT (Saneyoshi et al. 2002). This process is controlled by the calcium-dependent phosphatase calcineurin, thereby indicating NFAT as a downstream effector of the Wnt/ $\mathrm{Ca}^{2+}$ pathway. Indeed, Wnt5a can induce slight activation of an NFAT luciferase reporter in a Dvl-dependent manner in mouse F9 teratocarcinoma cells overexpressing Fzd2 (Ma et al. 2010). However, the precise requirement for $\mathrm{Dvl}$ in Wnt $/ \mathrm{Ca}^{2+}$ signaling remains to be deter- mined (Winklbauer et al. 2001; Sheldahl et al. 2003).

\section{CONCLUDING REMARKS}

Probing any of the alternative Wnt-signaling responses discussed above will remain a challenge until their precise molecular makeup is unraveled. For this, more specific players need to be identified, and the exact temporal order of signaling events needs to be revealed. One of the major challenges for future research will be to grasp how the different Wnt-signaling responses interact during development. For instance, Wnt $/ \beta$-catenin and Wnt $/ \mathrm{Ca}^{2+}$ signaling were shown to have opposing activities in convergent extension, with PKC and CamKII impacting on the signaling activities of $\beta$-catenin (Kuhl et al. 2001). Likewise, distinct Wntsignaling pathways were shown to have opposing roles in tail fin regeneration (Stoick-Cooper et al. 2007). In Drosophila, an attractive wnt $4 / f z$ and a repulsive $w n t 5 / r y k$ signal together control salivary gland migration (Harris and Beckendorf 2007). As such, multiple Wnt pathways might collaborate in controlling complex morphogenetic events, by each regulating different aspects of cell polarization and directional migration. For instance, development of the organ of Corti in the cochlea, which has become the mammalian paradigm for studying PCP, displays aspects of both PCP and CE. Whereas disruption of Vangl2 function causes the typical misorientation of inner ear hair cells associated with the former, loss of Wnt5a results in a shorter and wider cochlear duct, with an extra row of hair cells, more reminiscent of the latter (Montcouquiol et al. 2003; Qian et al. 2007). It is evident, however, that few if any of the extracellular and transmembrane components are exclusively dedicated to a single branch of the pathway. This includes proteins that were previously thought to be solely required for Wnt $/ \beta$ catenin signaling, such as Lrp6, showing that cross talk between the different branches might be more common than previously anticipated (Tahinci et al. 2007; Andersson et al. 2010).

A second aspect worthy of attention concerns the initiation of the different signaling 
events. At present, our understanding of how the cellular context determines the assembly of Wnt/(co-)receptor complexes, and how these complexes elicit specific responses remains ill understood. Recent data suggest that part of the answer may lie in the localization of receptor complexes to distinct microdomains within the cell membrane and corresponding different mechanisms of receptor internalization (Sato et al. 2010). As the literature on this topic is expanding, it is important to remember that at the same time many of the ligand and receptor combinations remain unexplored. As a result, we have only begun to uncover the tip of the iceberg when it comes to understanding the role of alternative Wnt signaling in development and disease.

\section{ACKNOWLEDGMENTS}

This work is supported by a KWF fellowship from the Dutch Cancer Society.

\section{REFERENCES}

Abu-Elmagd M, Garcia-Morales C, Wheeler GN. 2006. Frizzled7 mediates canonical Wnt signaling in neural crest induction. Dev Biol 298: 285-298.

Adler PN. 1992. The genetic control of tissue polarity in Drosophila. Bioessays 14: 735-741.

Afzal AR, Rajab A, Fenske CD, Oldridge M, Elanko N, Ternes-Pereira E, Tuysuz B, Murday VA, Patton MA, Wilkie AO, et al. 2000. Recessive Robinow syndrome, allelic to dominant brachydactyly type $\mathrm{B}$, is caused by mutation of ROR2. Nat Genet 25: 419-422.

Andersson ER, Bryjova L, Biris K, Yamaguchi TP, Arenas E, Bryja V. 2010. Genetic interaction between Lrp6 and Wnt5a during mouse development. Dev Dyn 239: 237245.

Antic D, Stubbs JL, Suyama K, Kintner C, Scott MP, Axelrod JD. 2010. Planar cell polarity enables posterior localization of nodal cilia and left-right axis determination during mouse and Xenopus embryogenesis. PLoS ONE 5: e8999.

Axelrod JD, Miller JR, Shulman JM, Moon RT, Perrimon N. 1998. Differential recruitment of Dishevelled provides signaling specificity in the planar cell polarity and Wingless signaling pathways. Genes Dev 12: 2610-2622.

Baker NE. 1987. Molecular cloning of sequences from wingless, a segment polarity gene in Drosophila: The spatial distribution of a transcript in embryos. $E M B O \mathrm{~J}$ 6: $1765-1773$.

Bayly R, Axelrod JD. 2011. Pointing in the right direction: New developments in the field of planar cell polarity. Nat Rev Genet 12: 385-391.
Berndt JD, Aoyagi A, Yang P, Anastas JN, Tang L, Moon RT. 2011. Mindbomb 1, an E3 ubiquitin ligase, forms a complex with RYK to activate Wnt $/ \beta$-catenin signaling. J Cell Biol 194: 737-750.

Bhanot P, Brink M, Samos CH, Hsieh JC, Wang Y, Macke JP, Andrew D, Nathans J, Nusse R. 1996. A new member of the frizzled family from Drosophila functions as a Wingless receptor. Nature 382: 225-230.

Bhanot P, Fish M, Jemison JA, Nusse R, Nathans J, Cadigan KM. 1999. Frizzled and Dfrizzled-2 function as redundant receptors for Wingless during Drosophila embryonic development. Development 126: 4175-4186.

Bhat KM. 1998. frizzled and frizzled 2 play a partially redundant role in Wingless signaling and have similar requirements to Wingless in neurogenesis. Cell 95: 1027-1036.

Bilic J, Huang YL, Davidson G, Zimmermann T, Cruciat CM, Bienz M, Niehrs C. 2007. Wnt induces LRP6 signalosomes and promotes Dishevelled-dependent LRP6 phosphorylation. Science 316: 1619-1622.

Billiard J, Way DS, Seestaller-Wehr LM, Moran RA, Mangine A, Bodine PV. 2005. The orphan receptor tyrosine kinase Ror2 modulates canonical Wnt signaling in osteoblastic cells. Mol Endocrinol 19: 90-101.

Boutros M, Paricio N, Strutt DI, Mlodzik M. 1998. Dishevelled activates JNK and discriminates between JNK pathways in planar polarity and wingless signaling. Cell 94: 109-118.

Boutros M, Mihaly J, Bouwmeester T, Mlodzik M. 2000. Signaling specificity by Frizzled receptors in Drosophila. Science 288: 1825-1828.

Carreira-Barbosa F, Concha ML, Takeuchi M, Ueno N, Wilson SW, Tada M. 2003. Prickle 1 regulates cell movements during gastrulation and neuronal migration in zebrafish. Development 130: 4037-4046.

Cervantes S, Yamaguchi TP, Hebrok M. 2009. Wnt5a is essential for intestinal elongation in mice. Dev Biol 326: 285-294.

Cha SW, Tadjuidje E, Tao Q, Wylie C, Heasman J. 2008. Wnt5a and Wnt11 interact in a maternal Dkk1-regulated fashion to activate both canonical and non-canonical signaling in Xenopus axis formation. Development 135: 3719-3729.

Cha SW, Tadjuidje E, White J, Wells J, Mayhew C, Wylie C, Heasman J. 2009. Wnt11/5a complex formation caused by tyrosine sulfation increases canonical signaling activity. Curr Biol 19: 1573-1580.

Chen WS, Antic D, Matis M, Logan CY, Povelones M, Anderson GA, Nusse R, Axelrod JD. 2008. Asymmetric homotypic interactions of the atypical cadherin flamingo mediate intercellular polarity signaling. Cell 133: $1093-$ 1105.

Choi KW, Benzer S. 1994. Rotation of photoreceptor clusters in the developing Drosophila eye requires the nemo gene. Cell 78: 125-136.

Choi SC, Han JK. 2002. Xenopus Cdc42 regulates convergent extension movements during gastrulation through Wnt/ $\mathrm{Ca}^{2+}$ signaling pathway. Dev Biol 244: 342-357.

Curtin JA, Quint E, Tsipouri V, Arkell RM, Cattanach B, Copp AJ, Henderson DJ, Spurr N, Stanier P, Fisher EM, et al. 2003. Mutation of Celsr1 disrupts planar polarity of 
inner ear hair cells and causes severe neural tube defects in the mouse. Curr Biol 13: 1129-1133.

Dabdoub A, Kelley MW. 2005. Planar cell polarity and a potential role for a Wnt morphogen gradient in stereociliary bundle orientation in the mammalian inner ear. J Neurobiol 64: 446-457.

Dabdoub A, Donohue MJ, Brennan A, Wolf V, Montcouquiol M, Sassoon DA, Hseih JC, Rubin JS, Salinas PC, Kelley MW. 2003. Wnt signaling mediates reorientation of outer hair cell stereociliary bundles in the mammalian cochlea. Development 130: 2375-2384.

Darken RS, Scola AM, Rakeman AS, Das G, Mlodzik M, Wilson PA. 2002. The planar polarity gene strabismus regulates convergent extension movements in Xenopus. EMBO J 21: 976-985.

Das G, Jenny A, Klein TJ, Eaton S, Mlodzik M. 2004. Diego interacts with Prickle and Strabismus/Van Gogh to localize planar cell polarity complexes. Development 131: 4467-4476.

Davidson LA, Keller RE. 1999. Neural tube closure in Xenopus laevis involves medial migration, directed protrusive activity, cell intercalation and convergent extension. Development 126: $4547-4556$.

Deans MR, Antic D, Suyama K, Scott MP, Axelrod JD, Goodrich LV. 2007. Asymmetric distribution of Prickle-like 2 reveals an early underlying polarization of vestibular sensory epithelia in the inner ear. J Neurosci 27: 3139-3147.

Devenport D, Fuchs E. 2008. Planar polarization in embryonic epidermis orchestrates global asymmetric morphogenesis of hair follicles. Nat Cell Biol 10: 1257-1268.

Djiane A, Riou J, Umbhauer M, Boucaut J, Shi D. 2000. Role of frizzled 7 in the regulation of convergent extension movements during gastrulation in Xenopus laevis. Development 127: 3091-3100.

Du SJ, Purcell SM, Christian JL, McGrew LL, Moon RT. 1995. Identification of distinct classes and functional domains of Wnts through expression of wild-type and chimeric proteins in Xenopus embryos. Mol Cell Biol 15: 2625-2634.

Endo M, Nishita M, Minami Y. 2012. Analysis of Wnt/planar cell polarity pathway in cultured cells. Methods Mol Biol 839: 201-214

Etheridge SL, Ray S, Li S, Hamblet NS, Lijam N, Tsang M, Greer J, Kardos N, Wang J, Sussman DJ, et al. 2008. Murine Dishevelled 3 functions in redundant pathways with Dishevelled 1 and 2 in normal cardiac outflow tract, cochlea, and neural tube development. PLoS Genet 4: e1000259.

Feike AC, Rachor K, Gentzel M, Schambony A. 2010. Wnt5a/Ror2-induced upregulation of xPAPC requires xShcA. Biochem Biophys Res Commun 400: 500-506.

Fiedler M, Mendoza-Topaz C, Rutherford TJ, Mieszczanek J, Bienz M. 2011. Dishevelled interacts with the DIX domain polymerization interface of Axin to interfere with its function in down-regulating $\beta$-catenin. Proc Natl Acad Sci 108: 1937-1942.

Fossat N, Jones V, Khoo PL, Bogani D, Hardy A, Steiner K, Mukhopadhyay M, Westphal H, Nolan PM, Arkell R, et al. 2011. Stringent requirement of a proper level of canonical WNT signalling activity for head formation in mouse embryo. Development 138: 667-676.
Fukuda T, Chen L, Endo T, Tang L, Lu D, Castro JE, Widhopf GF II, Rassenti LZ, Cantwell MJ, Prussak CE, et al. 2008. Antisera induced by infusions of autologous Ad-CD154leukemia B cells identify ROR1 as an oncofetal antigen and receptor for Wnt5a. Proc Natl Acad Sci 105: $3047-$ 3052.

Gao B, Song H, Bishop K, Elliot G, Garrett L, English MA, Andre P, Robinson J, Sood R, Minami Y, et al. 2011. Wnt signaling gradients establish planar cell polarity by inducing Vangl2 phosphorylation through Ror2. Dev Cell 20: $163-176$.

Gentile A, Lazzari L, Benvenuti S, Trusolino L, Comoglio PM. 2011. Ror1 is a pseudokinase that is crucial for Metdriven tumorigenesis. Cancer Res 71: 3132-3141.

Gleason JE, Szyleyko EA, Eisenmann DM. 2006. Multiple redundant Wnt signaling components function in two processes during C. elegans vulval development. Dev Biol 298: $442-457$.

Goodrich LV, Strutt D. 2011. Principles of planar polarity in animal development. Development 138: 1877-1892.

Gray RS, Abitua PB, Wlodarczyk BJ, Szabo-Rogers HL, Blanchard O, Lee I, Weiss GS, Liu KJ, Marcotte EM, Wallingford JB, et al. 2009. The planar cell polarity effector Fuz is essential for targeted membrane trafficking, ciliogenesis and mouse embryonic development. Nat Cell Biol 11: $1225-1232$.

Gray RS, Roszko I, Solnica-Krezel L. 2011. Planar cell polarity: Coordinating morphogenetic cell behaviors with embryonic polarity. Dev Cell 21: 120-133.

Green JL, Inoue T, Sternberg PW. 2007. The C. elegans ROR receptor tyrosine kinase, CAM-1, non-autonomously inhibits the Wnt pathway. Development 134: 4053-4062.

Green JL, Inoue T, Sternberg PW. 2008. Opposing Wnt pathways orient cell polarity during organogenesis. Cell 134: 646-656.

Guder C, Philipp I, Lengfeld T, Watanabe H, Hobmayer B, Holstein TW. 2006. The Wnt code: Cnidarians signal the way. Oncogene 25: 7450-7460.

Guo N, Hawkins C, Nathans J. 2004. Frizzled6 controls hair patterning in mice. Proc Natl Acad Sci 101: 9277-9281.

Habas R, Kato Y, He X. 2001. Wnt/Frizzled activation of Rho regulates vertebrate gastrulation and requires a novel Formin homology protein Daam1. Cell 107: 843-854.

Habas R, Dawid IB, He X. 2003. Coactivation of Rac and Rho by Wnt/Frizzled signaling is required for vertebrate gastrulation. Genes Dev 17: 295-309.

Hamblet NS, Lijam N, Ruiz-Lozano P, Wang J, Yang Y, Luo Z, Mei L, Chien KR, Sussman DJ, Wynshaw-Boris A. 2002. Dishevelled 2 is essential for cardiac outflow tract development, somite segmentation and neural tube closure. Development 129: 5827-5838.

Harris KE, Beckendorf SK. 2007. Different Wnt signals act through the Frizzled and RYK receptors during Drosophila salivary gland migration. Development 134: $2017-$ 2025.

He X, Saint-Jeannet JP, Wang Y, Nathans J, Dawid I, Varmus H. 1997. A member of the Frizzled protein family mediating axis induction by Wnt-5A. Science 275: 1652-1654.

Heisenberg CP, Tada M, Rauch GJ, Saude L, Concha ML, Geisler R, Stemple DL, Smith JC, Wilson SW. 2000. 
Silberblick/Wnt11 mediates convergent extension movements during zebrafish gastrulation. Nature 405: 76-81.

Hertzano R, Montcouquiol M, Rashi-Elkeles S, Elkon R, Yucel R, Frankel WN, Rechavi G, Moroy T, Friedman TB, Kelley MW, et al. 2004. Transcription profiling of inner ears from Pou4f3(ddl/ddl) identifies Gfil as a target of the Pou4f3 deafness gene. Hum Mol Genet 13: 2143-2153.

Heydeck W, Liu A. 2011. PCP effector proteins inturned and fuzzy play nonredundant roles in the patterning but not convergent extension of mammalian neural tube. Dev Dyn 240: 1938-1948.

Ho HY, Susman MW, Bikoff JB, Ryu YK, Jonas AM, Hu L, Kuruvilla R, Greenberg ME. 2012. Wnt5a-Ror-Dishevelled signaling constitutes a core developmental pathway that controls tissue morphogenesis. Proc Natl Acad Sci 109: 4044-4051.

Holmen SL, Salic A, Zylstra CR, Kirschner MW, Williams BO. 2002. A novel set of Wnt-Frizzled fusion proteins identifies receptor components that activate $\beta$-catenindependent signaling. J Biol Chem 277: 34727-34735.

Inoue T, Oz HS, Wiland D, Gharib S, Deshpande R, Hill RJ, Katz WS, Sternberg PW. 2004. C. elegans LIN-18 is a Ryk ortholog and functions in parallel to LIN-17/Frizzled in Wnt signaling. Cell 118: 795-806.

Janssen R, Le Gouar M, Pechmann M, Poulin F, Bolognesi R, Schwager EE, Hopfen C, Colbourne JK, Budd GE, Brown SJ, et al. 2010. Conservation, loss, and redeployment of Wnt ligands in protostomes: Implications for understanding the evolution of segment formation. BMC Evol Biol 10: 374.

Jenny A. 2010. Planar cell polarity signaling in the Drosophila eye. Curr Top Dev Biol 93: 189-227.

Jenny A, Reynolds-Kenneally J, Das G, Burnett M, Mlodzik M. 2005. Diego and Prickle regulate Frizzled planar cell polarity signalling by competing for Dishevelled binding. Nat Cell Biol 7: 691-697.

Jue SF, Bradley RS, Rudnicki JA, Varmus HE, Brown AM 1992. The mouse Wnt-1 gene can act via a paracrine mechanism in transformation of mammary epithelial cells. Mol Cell Biol 12: 321-328.

Karner CM, Chirumamilla R, Aoki S, Igarashi P, Wallingford JB, Carroll TJ. 2009. Wnt9b signaling regulates planar cell polarity and kidney tubule morphogenesis. Nat Genet 41: 793-799.

Katanaev VL, Ponzielli R, Semeriva M, Tomlinson A. 2005. Trimeric G protein-dependent frizzled signaling in Drosophila. Cell 120: 111-122.

Keeble TR, Halford MM, Seaman C, Kee N, Macheda M, Anderson RB, Stacker SA, Cooper HM. 2006. The Wnt receptor Ryk is required for Wnt5a-mediated axon guidance on the contralateral side of the corpus callosum. J Neurosci 26: $5840-5848$.

Keller R, Danilchik M. 1988. Regional expression, pattern and timing of convergence and extension during gastrulation of Xenopus laevis. Development 103: 193-209.

Keller RE, Danilchik M, Gimlich R, Shih J. 1985. The function and mechanism of convergent extension during gastrulation of Xenopus laevis. J Embryol Exp Morphol 89: 185-209.
Kennerdell JR, Carthew RW. 1998. Use of dsRNA-mediated genetic interference to demonstrate that frizzled and frizzled 2 act in the Wingless pathway. Cell 95: 1017-1026.

Kibar Z, Vogan KJ, Groulx N, Justice MJ, Underhill DA, Gros P. 2001. Ltap, a mammalian homolog of Drosophila Strabismus/Van Gogh, is altered in the mouse neural tube mutant Loop-tail. Nat Genet 28: 251-255.

Kibar Z, Salem S, Bosoi CM, Pauwels E, De Marco P, Merello E, Bassuk AG, Capra V, Gros P. 2011. Contribution of VANGL2 mutations to isolated neural tube defects. Clin Genet 80: 76-82.

Kilian B, Mansukoski H, Barbosa FC, Ulrich F, Tada M, Heisenberg CP. 2003. The role of Ppt/Wnt5 in regulating cell shape and movement during zebrafish gastrulation. Mech Dev 120: 467-476.

Kim GH, Han JK. 2005. JNK and ROK $\alpha$ function in the noncanonical Wnt/RhoA signaling pathway to regulate Xenopus convergent extension movements. Dev Dyn 232: 958-968.

Kim GH, Her JH, Han JK. 2008. Ryk cooperates with Frizzled 7 to promote Wnt11-mediated endocytosis and is essential for Xenopus laevis convergent extension movements. J Cell Biol 182: 1073-1082.

Kockel L, Zeitlinger J, Staszewski LM, Mlodzik M, Bohmann D. 1997. Jun in Drosophila development: Redundant and nonredundant functions and regulation by two MAPK signal transduction pathways. Genes Dev 11: 1748-1758.

Krasnow RE, Adler PN. 1994. A single frizzled protein has a dual function in tissue polarity. Development 120: 1883-1893.

Kuhl M, Sheldahl LC, Malbon CC, Moon RT. 2000. $\mathrm{Ca}^{2+}$ / calmodulin-dependent protein kinase II is stimulated by Wnt and Frizzled homologs and promotes ventral cell fates in Xenopus. J Biol Chem 275: 12701-12711.

Kuhl M, Geis K, Sheldahl LC, Pukrop T, Moon RT, Wedlich D. 2001. Antagonistic regulation of convergent extension movements in Xenopus by Wnt/ $\beta$-catenin and $\mathrm{Wnt} /$ $\mathrm{Ca}^{2+}$ signaling. Mech Dev 106: 61-76.

Lee H, Adler PN. 2002. The function of the Frizzled pathway in the Drosophila wing is dependent on Inturned and Fuzzy. Genetics 160: 1535-1547.

Le Floch N, Rivat C, De Wever O, Bruyneel E, Mareel M, Dale T, Gespach C. 2005. The proinvasive activity of Wnt2 is mediated through a noncanonical Wnt pathway coupled to GSK-3 $\beta$ and c-Jun/AP-1 signaling. FASEB J 19: 144-146.

Li L, Yuan H, Xie W, Mao J, Caruso AM, McMahon A, Sussman DJ, Wu D. 1999. Dishevelled proteins lead to two signaling pathways. Regulation of LEF-1 and c-Jun N-terminal kinase in mammalian cells. J Biol Chem 274: $129-134$.

Li C, Chen H, Hu L, Xing Y, Sasaki T, Villosis MF, Li J, Nishita M, Minami Y, Minoo P. 2008. Ror2 modulates the canonical Wnt signaling in lung epithelial cells through cooperation with Fzd2. BMC Mol Biol 9: 11.

Lin S, Baye LM, Westfall TA, Slusarski DC. 2010. Wnt5bRyk pathway provides directional signals to regulate gastrulation movement. J Cell Biol 190: 263-278.

Liu X, Liu T, Slusarski DC, Yang-Snyder J, Malbon CC, Moon RT, Wang H. 1999. Activation of a Frizzled- $2 / \beta$ adrenergic receptor chimera promotes Wnt signaling and 
differentiation of mouse F9 teratocarcinoma cells via Goo and Got. Proc Natl Acad Sci 96: 14383-14388.

Liu Y, Shi J, Lu CC, Wang ZB, Lyuksyutova AI, Song XJ, Zou Y. 2005. Ryk-mediated Wnt repulsion regulates posterior-directed growth of corticospinal tract. Nat Neurosci 8: 1151-1159.

Liu Y, Ross JF, Bodine PV, Billiard J. 2007. Homodimerization of Ror2 tyrosine kinase receptor induces $14-3-3 \beta$ phosphorylation and promotes osteoblast differentiation and bone formation. Mol Endocrinol 21: 3050-3061.

Liu Y, Rubin B, Bodine PV, Billiard J. 2008. Wnt5a induces homodimerization and activation of Ror2 receptor tyrosine kinase. J Cell Biochem 105: 497-502.

Lu W, Yamamoto V, Ortega B, Baltimore D. 2004. Mammalian Ryk is a Wnt coreceptor required for stimulation of neurite outgrowth. Cell 119: 97-108.

Lyu J, Yamamoto V, Lu W. 2008. Cleavage of the Wnt receptor Ryk regulates neuronal differentiation during cortical neurogenesis. Dev Cell 15: 773-780.

Lyu J, Wesselschmidt RL, Lu W. 2009. Cdc37 regulates Ryk signaling by stabilizing the cleaved Ryk intracellular domain. J Biol Chem 284: 12940-12948.

Ma L, Wang HY. 2007. Mitogen-activated protein kinase p38 regulates the Wnt/cyclic GMP/Ca ${ }^{2+}$ non-canonical pathway. J Biol Chem 282: 28980-28990.

Ma L, Wang Y, Malbon CC, Wang HY. 2010. Dishevelled-3 $\mathrm{C}$-terminal His single amino acid repeats are obligate for Wnt5a activation of non-canonical signaling. J Mol Signal 5: 19.

MacLeod RJ, Hayes M, Pacheco I. 2007. Wnt5a secretion stimulated by the extracellular calcium-sensing receptor inhibits defective Wnt signaling in colon cancer cells. Am J Physiol Gastrointest Liver Physiol 293: G403-G411.

Marinissen MJ, Chiariello M, Tanos T, Bernard O, Narumiya S, Gutkind JS. 2004. The small GTP-binding protein RhoA regulates c-jun by a ROCK-JNK signaling axis. Mol Cell 14: 29-41.

Matsuda T, Suzuki H, Oishi I, Kani S, Kuroda Y, Komori T, Sasaki A, Watanabe K, Minami Y. 2003. The receptor tyrosine kinase Ror2 associates with the melanoma-associated antigen (MAGE) family protein Dlxin-1 and regulates its intracellular distribution. J Biol Chem 278: 29057-29064.

Matthews HK, Marchant L, Carmona-Fontaine C, Kuriyama S, Larrain J, Holt MR, Parsons M, Mayor R. 2008. Directional migration of neural crest cells in vivo is regulated by Syndecan-4/Racl and non-canonical Wnt signaling/RhoA. Development 135: 1771-1780.

Maung SM, Jenny A. 2011. Planar cell polarity in Drosophila. Organogenesis 7: 165-179.

McMahon AP, Moon RT. 1989. Ectopic expression of the proto-oncogene int-1 in Xenopus embryos leads to duplication of the embryonic axis. Cell 58: 1075-1084.

Medina A, Reintsch W, Steinbeisser H. 2000. Xenopus frizzled 7 can act in canonical and non-canonical Wnt signaling pathways: Implications on early patterning and morphogenesis. Mech Dev 92: 227-237.

Mikels AJ, Nusse R. 2006. Purified Wnt5a protein activates or inhibits $\beta$-catenin-TCF signaling depending on receptor context. PLoS Biol 4: e115.
Mikels A, Minami Y, Nusse R. 2009. Ror2 receptor requires tyrosine kinase activity to mediate Wnt5A signaling. $J$ Biol Chem 284: 30167-30176.

Moeller H, Jenny A, Schaeffer HJ, Schwarz-Romond T, Mlodzik M, Hammerschmidt M, Birchmeier W. 2006. Diversin regulates heart formation and gastrulation movements in development. Proc Natl Acad Sci 103: 15900-15905.

Montcouquiol M, Rachel RA, Lanford PJ, Copeland NG, Jenkins NA, Kelley MW. 2003. Identification of Vangl2 and Scrb1 as planar polarity genes in mammals. Nature 423: 173-177.

Montcouquiol M, Sans N, Huss D, Kach J, Dickman JD, Forge A, Rachel RA, Copeland NG, Jenkins NA, Bogani D, et al. 2006. Asymmetric localization of Vangl2 and Fz3 indicate novel mechanisms for planar cell polarity in mammals. J Neurosci 26: 5265-5275.

Moon RT, Campbell RM, Christian JL, McGrew LL, Shih J, Fraser S. 1993. Xwnt-5A: A maternal Wnt that affects morphogenetic movements after overexpression in embryos of Xenopus laevis. Development 119: 97-111.

Moriguchi T, Kawachi K, Kamakura S, Masuyama N, Yamanaka H, Matsumoto K, Kikuchi A, Nishida E. 1999. Distinct domains of mouse dishevelled are responsible for the c-Jun $\mathrm{N}$-terminal kinase/stress-activated protein kinase activation and the axis formation in vertebrates. $J$ Biol Chem 274: 30957-30962.

Nemeth MJ, Topol L, Anderson SM, Yang Y, Bodine DM. 2007. Wnt5a inhibits canonical Wnt signaling in hematopoietic stem cells and enhances repopulation. Proc Natl Acad Sci 104: 15436-15441.

Nishita M, Itsukushima S, Nomachi A, Endo M, Wang Z, Inaba D, Qiao S, Takada S, Kikuchi A, Minami Y. 2010. Ror2/Frizzled complex mediates Wnt5a-induced AP-1 activation by regulating Dishevelled polymerization. Mol Cell Biol 30: 3610-3619.

Noordermeer J, Klingensmith J, Perrimon N, Nusse R. 1994. dishevelled and armadillo act in the Wingless signalling pathway in Drosophila. Nature 367: 80-83.

Ohkawara B, Niehrs C. 2011. An ATF2-based luciferase reporter to monitor non-canonical Wnt signaling in Xenopus embryos. Dev Dyn 240: 188-194.

Oishi I, Takeuchi S, Hashimoto R, Nagabukuro A, Ueda T, Liu ZJ, Hatta T, Akira S, Matsuda Y, Yamamura H, et al. 1999. Spatio-temporally regulated expression of receptor tyrosine kinases, mRor1, mRor2, during mouse development: Implications in development and function of the nervous system. Genes Cells 4: 41-56.

Oishi I, Suzuki H, Onishi N, Takada R, Kani S, Ohkawara B Koshida I, Suzuki K, Yamada G, Schwabe GC, et al. 2003. The receptor tyrosine kinase Ror2 is involved in noncanonical Wnt5a/JNK signalling pathway. Genes Cells 8: $645-654$.

Paganoni S, Bernstein J, Ferreira A. 2010. Ror1-Ror2 complexes modulate synapse formation in hippocampal neurons. Neuroscience 165: 1261-1274.

Park TJ, Haigo SL, Wallingford JB. 2006. Ciliogenesis defects in embryos lacking inturned or fuzzy function are associated with failure of planar cell polarity and Hedgehog signaling. Nat Genet 38: 303-311.

Penzo-Mendez A, Umbhauer M, Djiane A, Boucaut JC, Riou JF. 2003. Activation of G $\beta \gamma$ signaling downstream 
of Wnt-11/Xfz7 regulates Cdc42 activity during Xenopus gastrulation. Dev Biol 257: 302-314.

Person AD, Beiraghi S, Sieben CM, Hermanson S, Neumann AN, Robu ME, Schleiffarth JR, Billington CJ Jr, van Bokhoven H, Hoogeboom JM, et al. 2010. WNT5A mutations in patients with autosomal dominant Robinow syndrome. Dev Dyn 239: 327-337.

Phillips HM, Murdoch JN, Chaudhry B, Copp AJ, Henderson DJ. 2005. Vangl2 acts via RhoA signaling to regulate polarized cell movements during development of the proximal outflow tract. Circ Res 96: 292-299.

Qian D, Jones C, Rzadzinska A, Mark S, Zhang X, Steel KP, Dai X, Chen P. 2007. Wnt5a functions in planar cell polarity regulation in mice. Dev Biol 306: 121-133.

Rijsewijk F, Schuermann M, Wagenaar E, Parren P, Weigel D, Nusse R. 1987. The Drosophila homolog of the mouse mammary oncogene int-1 is identical to the segment polarity gene wingless. Cell 50: 649-657.

Roarty K, Baxley SE, Crowley MR, Frost AR, Serra R. 2009. Loss of TGF- $\beta$ or Wnt5a results in an increase in Wnt $/ \beta$ catenin activity and redirects mammary tumour phenotype. Breast Cancer Res 11: R19.

Rosso SB, Sussman D, Wynshaw-Boris A, Salinas PC. 2005. Wnt signaling through Dishevelled, Rac and JNK regulates dendritic development. Nat Neurosci 8: 34-42.

Rothbacher U, Laurent MN, Deardorff MA, Klein PS, Cho KW, Fraser SE. 2000. Dishevelled phosphorylation, subcellular localization and multimerization regulate its role in early embryogenesis. EMBO J 19: 1010-1022.

Rulifson EJ, Wu CH, Nusse R. 2000. Pathway specificity by the bifunctional receptor Frizzled is determined by affinity for Wingless. Mol Cell 6: 117-126.

Sakurai M, Aoki T, Yoshikawa S, Santschi LA, Saito H, Endo K, Ishikawa K, Kimura K, Ito K, Thomas JB, et al. 2009. Differentially expressed Drl and Drl-2 play opposing roles in Wnt5 signaling during Drosophila olfactory system development. J Neurosci 29: 4972-4980.

Saldanha J, Singh J, Mahadevan D. 1998. Identification of a Frizzled-like cysteine rich domain in the extracellular region of developmental receptor tyrosine kinases. Protein Sci 7: 1632-1635.

Sammar M, Stricker S, Schwabe GC, Sieber C, Hartung A, Hanke M, Oishi I, Pohl J, Minami Y, Sebald W, et al. 2004. Modulation of GDF5/BRI-b signalling through interaction with the tyrosine kinase receptor Ror2. Genes Cells 9: 1227-1238.

Sammar M, Sieber C, Knaus P. 2009. Biochemical and functional characterization of the Ror2/BRIb receptor complex. Biochem Biophys Res Commun 381: 1-6.

Saneyoshi T, Kume S, Amasaki Y, Mikoshiba K. 2002. The Wnt/calcium pathway activates NF-AT and promotes ventral cell fate in Xenopus embryos. Nature 417: $295-$ 299.

Sato A, Yamamoto H, Sakane H, Koyama H, Kikuchi A. 2010. Wnt5a regulates distinct signalling pathways by binding to Frizzled2. EMBO J 29: 41-54.

Schulte G. 2010. International Union of Basic and Clinical Pharmacology. LXXX. The class Frizzled receptors. Pharmacol Rev 62: 632-667.

Schwabe GC, Trepczik B, Suring K, Brieske N, Tucker AS, Sharpe PT, Minami Y, Mundlos S. 2004. Ror2 knockout mouse as a model for the developmental pathology of autosomal recessive Robinow syndrome. Dev Dyn 229: $400-410$.

Schwarzer W, Witte F, Rajab A, Mundlos S, Stricker S. 2009. A gradient of ROR2 protein stability and membrane localization confers brachydactyly type B or Robinow syndrome phenotypes. Hum Mol Genet 18: 4013-4021.

Schwarz-Romond T, Fiedler M, Shibata N, Butler PJ, Kikuchi A, Higuchi Y, Bienz M. 2007a. The DIX domain of Dishevelled confers Wnt signaling by dynamic polymerization. Nat Struct Mol Biol 14: 484-492.

Schwarz-Romond T, Metcalfe C, Bienz M. 2007b. Dynamic recruitment of axin by Dishevelled protein assemblies. J Cell Sci 120: 2402-2412.

Seo JH, Zilber Y, Babayeva S, Liu J, Kyriakopoulos P, De Marco P, Merello E, Capra V, Gros P, Torban E. 2011. Mutations in the planar cell polarity gene, Fuzzy, are associated with neural tube defects in humans. Hum Mol Genet 20: 4324-4333.

Shabani M, Asgarian-Omran H, Vossough P, Sharifian RA, Faranoush M, Ghragozlou S, Khoshnoodi J, Roohi A, Jeddi-Tehrani M, Mellstedt H, et al. 2008. Expression profile of orphan receptor tyrosine kinase (ROR1) and Wilms' tumor gene 1 (WT1) in different subsets of B-cell acute lymphoblastic leukemia. Leuk Lymphoma 49: 1360-1367.

Shafer B, Onishi K, Lo C, Colakoglu G, Zou Y. 2011. Vangl2 promotes Wnt/planar cell polarity-like signaling by antagonizing Dvll-mediated feedback inhibition in growth cone guidance. Dev Cell 20: 177-191.

Sheldahl LC, Park M, Malbon CC, Moon RT. 1999. Protein kinase $\mathrm{C}$ is differentially stimulated by Wnt and Frizzled homologs in a G-protein-dependent manner. Curr Biol 9: 695-698.

Sheldahl LC, Slusarski DC, Pandur P, Miller JR, Kuhl M, Moon RT. 2003. Dishevelled activates $\mathrm{Ca}^{2+}$ flux, PKC, and CamKII in vertebrate embryos. J Cell Biol 161: 769-777.

Shimizu H, Julius MA, Giarre M, Zheng Z, Brown AM, Kitajewski J. 1997. Transformation by Wnt family proteins correlates with regulation of $\beta$-catenin. Cell Growth Differ 8: 1349-1358.

Shimizu K, Sato M, Tabata T. 2011. The Wnt5/planar cell polarity pathway regulates axonal development of the Drosophila mushroom body neuron. I Neurosci 31: 4944-4954.

Siegfried E, Chou TB, Perrimon N. 1992. wingless signaling acts through zeste-white 3, the Drosophila homolog of glycogen synthase kinase- 3 , to regulate engrailed and establish cell fate. Cell 71: 1167-1179.

Siegfried E, Wilder EL, Perrimon N. 1994. Components of Wingless signalling in Drosophila. Nature 367: 76-80.

Slusarski DC, Corces VG, Moon RT. 1997a. Interaction of Wnt and a Frizzled homologue triggers G-protein-linked phosphatidylinositol signalling. Nature 390: 410-413.

Slusarski DC, Yang-Snyder J, Busa WB, Moon RT. 1997b. Modulation of embryonic intracellular $\mathrm{Ca}^{2+}$ signaling by Wnt-5A. Dev Biol 182: 114-120.

Sokol S, Christian JL, Moon RT, Melton DA. 1991. Injected Wnt RNA induces a complete body axis in Xenopus embryos. Cell 67: 741-752. 
Song H, Hu J, Chen W, Elliott G, Andre P, Gao B, Yang Y. 2010. Planar cell polarity breaks bilateral symmetry by controlling ciliary positioning. Nature 466: 378-382.

Stoick-Cooper CL, Weidinger G, Riehle KJ, Hubbert C, Major MB, Fausto N, Moon RT. 2007. Distinct Wnt signaling pathways have opposing roles in appendage regeneration. Development 134: 479-489.

Strutt DI, Weber U, Mlodzik M. 1997. The role of RhoA in tissue polarity and Frizzled signalling. Nature 387: $292-$ 295.

Sumanas S, Strege P, Heasman J, Ekker SC. 2000. The putative Wnt receptor Xenopus frizzled-7 functions upstream of $\beta$-catenin in vertebrate dorsoventral mesoderm patterning. Development 127: 1981-1990.

Tahinci E, Thorne CA, Franklin JL, Salic A, Christian KM, Lee LA, Coffey RJ, Lee E. 2007. Lrp6 is required for convergent extension during Xenopus gastrulation. Development 134: 4095-4106.

Taillebourg E, Moreau-Fauvarque C, Delaval K, Dura JM. 2005. In vivo evidence for a regulatory role of the kinase activity of the linotte/derailed receptor tyrosine kinase, a Drosophila Ryk ortholog. Dev Genes Evol 215: 158-163.

Tao Q, Yokota C, Puck H, Kofron M, Birsoy B, Yan D, Asashima M, Wylie CC, Lin X, Heasman J. 2005. Maternal Wnt11 activates the canonical Wnt signaling pathway required for axis formation in Xenopus embryos. Cell 120: $857-871$.

Thorpe CJ, Moon RT. 2004. nemo-like kinase is an essential co-activator of Wnt signaling during early zebrafish development. Development 131: 2899-2909.

Topol L, Jiang X, Choi H, Garrett-Beal L, Carolan PJ, Yang Y. 2003. Wnt-5a inhibits the canonical Wnt pathway by promoting GSK-3-independent $\beta$-catenin degradation. J Cell Biol 162: 899-908.

Torban E, Wang HJ, Groulx N, Gros P. 2004. Independent mutations in mouse Vangl2 that cause neural tube defects in looptail mice impair interaction with members of the Dishevelled family. J Biol Chem 279: 52703-52713.

Torban E, Patenaude AM, Leclerc S, Rakowiecki S, Gauthier S, Andelfinger G, Epstein DJ, Gros P. 2008. Genetic interaction between members of the Vangl family causes neural tube defects in mice. Proc Natl Acad Sci 105: 3449-3454.

Torres MA, Yang-Snyder JA, Purcell SM, DeMarais AA, McGrew LL, Moon RT. 1996. Activities of the Wnt-1 class of secreted signaling factors are antagonized by the Wnt$5 \mathrm{~A}$ class and by a dominant negative cadherin in early Xenopus development. J Cell Biol 133: 1123-1137.

Tree DR, Shulman JM, Rousset R, Scott MP, Gubb D, Axelrod JD. 2002. Prickle mediates feedback amplification to generate asymmetric planar cell polarity signaling. Cell 109: $371-381$.

Tufan AC, Daumer KM, DeLise AM, Tuan RS. 2002. AP-1 transcription factor complex is a target of signals from both WnT-7a and N-cadherin-dependent cell-cell adhesion complex during the regulation of limb mesenchymal chondrogenesis. Exp Cell Res 273: 197-203.

van Amerongen R, Nusse R. 2009. Towards an integrated view of Wnt signaling in development. Development 136: 3205-3214. van Bokhoven H, Celli J, Kayserili H, van Beusekom E, Balci S, Brussel W, Skovby F, Kerr B, Percin EF, Akarsu N, et al. 2000. Mutation of the gene encoding the ROR2 tyrosine kinase causes autosomal recessive Robinow syndrome. Nat Genet 25: 423-426.

van de Wetering M, Cavallo R, Dooijes D, van Beest M, van Es J, Loureiro J, Ypma A, Hursh D, Jones T, Bejsovec A, et al. 1997. Armadillo coactivates transcription driven by the product of the Drosophila segment polarity gene dTCF. Cell 88: 789-799.

van Wijk NV, Witte F, Feike AC, Schambony A, Birchmeier W, Mundlos S, Stricker S. 2009. The LIM domain protein Wtip interacts with the receptor tyrosine kinase Ror2 and inhibits canonical Wnt signalling. Biochem Biophys Res Commun 390: 211-216.

Veeman MT, Slusarski DC, Kaykas A, Louie SH, Moon RT. 2003. Zebrafish prickle, a modulator of noncanonical $\mathrm{Wnt} / \mathrm{Fz}$ signaling, regulates gastrulation movements. Curr Biol 13: 680-685.

Verkaar F, van Rosmalen JW, Smits JF, Blankesteijn WM, Zaman GJ. 2009. Stably overexpressed human Frizzled2 signals through the $\beta$-catenin pathway and does not activate $\mathrm{Ca}^{2+}$-mobilization in Human Embryonic Kidney 293 cells. Cell Signal 21: 22-33.

Verkaar F, Blankesteijn WM, Smits JF, Zaman GJ. 2010. $\beta$ Galactosidase enzyme fragment complementation for the measurement of Wnt $\beta$-catenin signaling. FASEB $J$ 24: 1205-1217.

Vinson CR, Conover S, Adler PN. 1989. A Drosophila tissue polarity locus encodes a protein containing seven potential transmembrane domains. Nature 338: 263-264.

Wallingford JB, Harland RM. 2001. Xenopus dishevelled signaling regulates both neural and mesodermal convergent extension: Parallel forces elongating the body axis. Development 128: 2581-2592.

Wallingford JB, Rowning BA, Vogeli KM, Rothbacher U, Fraser SE, Harland RM. 2000. Dishevelled controls cell polarity during Xenopus gastrulation. Nature 405: 81-85.

Wang J, Mark S, Zhang X, Qian D, Yoo SJ, Radde-Gallwitz K, Zhang Y, Lin X, Collazo A, Wynshaw-Boris A, et al. 2005. Regulation of polarized extension and planar cell polarity in the cochlea by the vertebrate PCP pathway. Nat Genet 37: $980-985$.

Wang J, Hamblet NS, Mark S, Dickinson ME, Brinkman BC, Segil N, Fraser SE, Chen P, Wallingford JB, WynshawBoris A. 2006a. Dishevelled genes mediate a conserved mammalian PCP pathway to regulate convergent extension during neurulation. Development 133: 1767-1778.

Wang Y, Guo N, Nathans J. 2006b. The role of Frizzled3 and Frizzled6 in neural tube closure and in the planar polarity of inner-ear sensory hair cells. J Neurosci 26: 2147-2156.

Wang Y, Chang H, Nathans J. 2010. When whorls collide: The development of hair patterns in frizzled 6 mutant mice. Development 137: 4091-4099.

Warga RM, Kimmel CB. 1990. Cell movements during epiboly and gastrulation in zebrafish. Development 108: 569-580.

Weber U, Paricio N, Mlodzik M. 2000. Jun mediates Frizzled-induced R3/R4 cell fate distinction and planar polarity determination in the Drosophila eye. Development 127: $3619-3629$. 
R. van Amerongen

Wilson PA, Oster G, Keller R. 1989. Cell rearrangement and segmentation in Xenopus: Direct observation of cultured explants. Development 105: 155-166.

Winkel A, Stricker S, Tylzanowski P, Seiffart V, Mundlos S, Gross G, Hoffmann A. 2008. Wnt-ligand-dependent interaction of TAK1 (TGF- $\beta$-activated kinase-1) with the receptor tyrosine kinase Ror2 modulates canonical Wntsignalling. Cell Signal 20: 2134-2144.

Winklbauer R, Medina A, Swain RK, Steinbeisser H. 2001 Frizzled-7 signalling controls tissue separation during Xenopus gastrulation. Nature 413: 856-860.

Witte F, Bernatik O, Kirchner K, Masek J, Mahl A, Krejci P, Mundlos S, Schambony A, Bryja V, Stricker S. 2010. Negative regulation of Wnt signaling mediated by CK1phosphorylated Dishevelled via Ror2. FASEB J 24: 24172426.

Wong LL, Adler PN. 1993. Tissue polarity genes of Drosophila regulate the subcellular location for prehair initiation in pupal wing cells. J Cell Biol 123: 209-221.

Wong GT, Gavin BJ, McMahon AP. 1994. Differential transformation of mammary epithelial cells by Wnt genes. Mol Cell Biol 14: 6278-6286.

Wouda RR, Bansraj MR, de Jong AW, Noordermeer JN, Fradkin LG. 2008. Src family kinases are required for WNT5 signaling through the Derailed/RYK receptor in the Drosophila embryonic central nervous system. Development 135: 2277-2287.

Wu M, Herman MA. 2006. A novel noncanonical Wnt pathway is involved in the regulation of the asymmetric B cell division in C. elegans. Dev Biol 293: 316-329.

Wu J, Mlodzik M. 2008. The frizzled extracellular domain is a ligand for Van Gogh/Stbm during nonautonomous planar cell polarity signaling. Dev Cell 15: 462-469.

Wu J, Klein TJ, Mlodzik M. 2004. Subcellular localization of frizzled receptors, mediated by their cytoplasmic tails, regulates signaling pathway specificity. PLoS Biol 2: e158.
Yamada M, Udagawa J, Matsumoto A, Hashimoto R, Hatta T, Nishita M, Minami Y, Otani H. 2010. Ror2 is required for midgut elongation during mouse development. Dev Dyn 239: 941-953.

Yamaguchi TP, Bradley A, McMahon AP, Jones S. 1999. A Wnt5a pathway underlies outgrowth of multiple structures in the vertebrate embryo. Development 126: 12111223.

Yamamoto S, Nishimura O, Misaki K, Nishita M, Minami Y, Yonemura S, Tarui H, Sasaki H. 2008. Cthrc1 selectively activates the planar cell polarity pathway of Wnt signaling by stabilizing the Wnt-receptor complex. Dev Cell 15: 23-36.

Yamanaka H, Moriguchi T, Masuyama N, Kusakabe M, Hanafusa H, Takada R, Takada S, Nishida E. 2002. JNK functions in the non-canonical Wnt pathway to regulate convergent extension movements in vertebrates. $E M B O$ Rep 3: 69-75.

Yates LL, Schnatwinkel C, Murdoch JN, Bogani D, Formstone CJ, Townsend S, Greenfield A, Niswander LA, Dean CH. 2010. The PCP genes Celsr 1 and Vangl2 are required for normal lung branching morphogenesis. Hum Mol Genet 19: 2251-2267.

Yoshikawa S, McKinnon RD, Kokel M, Thomas JB. 2003. Wnt-mediated axon guidance via the Drosophila Derailed receptor. Nature 422: 583-588.

Zeng H, Hoover AN, Liu A. 2010. PCP effector gene Inturned is an important regulator of cilia formation and embryonic development in mammals. Dev Biol 339: $418-428$.

Zhang Y, Levin M. 2009. Left-right asymmetry in the chick embryo requires core planar cell polarity protein Vangl2. Genesis 47: 719-728.

Zinovyeva AY, Yamamoto Y, Sawa H, Forrester WC. 2008. Complex network of Wnt signaling regulates neuronal migrations during Caenorhabditis elegans development. Genetics 179: 1357-1371. 


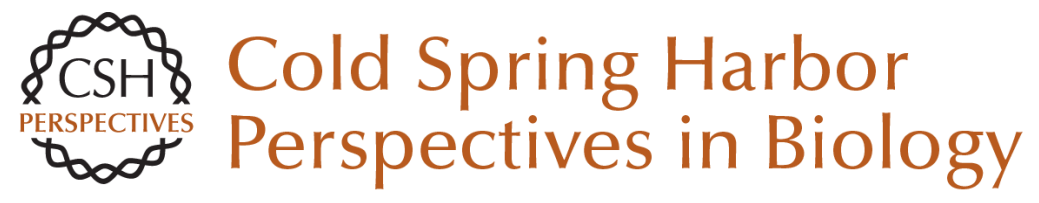

\section{Alternative Wnt Pathways and Receptors}

Renée van Amerongen

Cold Spring Harb Perspect Biol 2012; doi: 10.1101/cshperspect.a007914 originally published online August 30, 2012

\section{Subject Collection Wnt Signaling}

Wnt Signaling in Vertebrate Axis Specification Hiroki Hikasa and Sergei Y. Sokol

Secreted and Transmembrane Wnt Inhibitors and

Activators

Cristina-Maria Cruciat and Christof Niehrs

Wnt Signaling in Normal and Malignant

Hematopoiesis

William Lento, Kendra Congdon, Carlijn Voermans, et al.

Frizzled and LRP5/6 Receptors for Wnt/ $\beta$-Catenin

Signaling

Bryan T. MacDonald and Xi He

TCF/LEFs and Wnt Signaling in the Nucleus

Ken M. Cadigan and Marian L. Waterman

\section{Alternative Wnt Pathways and Receptors \\ Renée van Amerongen}

$\beta$-Catenin-Dependent Wnt Signaling in $C$. elegans:

Teaching an Old Dog a New Trick

Belinda M. Jackson and David M. Eisenmann

The Evolution of the Wnt Pathway

Thomas W. Holstein
The $\beta$-Catenin Destruction Complex Jennifer L. Stamos and William I. Weis

Wnt Signaling in Skin Development, Homeostasis, and Disease Xinhong Lim and Roel Nusse

Wnt Signaling in Bone Development and Disease:

Making Stronger Bone with Wnts Jean B. Regard, Zhendong Zhong, Bart O. Williams, et al.

Targeting Wnt Pathways in Disease Zachary F. Zimmerman, Randall T. Moon and Andy J. Chien

Wnt Signaling in Mammary Glands: Plastic Cell

Fates and Combinatorial Signaling Caroline M. Alexander, Shruti Goel, Saja A. Fakhraldeen, et al.

Wnt Signaling and Injury Repair Jemima L. Whyte, Andrew A. Smith and Jill A. Helms

Wnt Signaling and Forebrain Development Susan J. Harrison-Uy and Samuel J. Pleasure

Wnt Signaling in Neuromuscular Junction

Development

Kate Koles and Vivian Budnik

For additional articles in this collection, see http://cshperspectives.cshlp.org/cgi/collection/

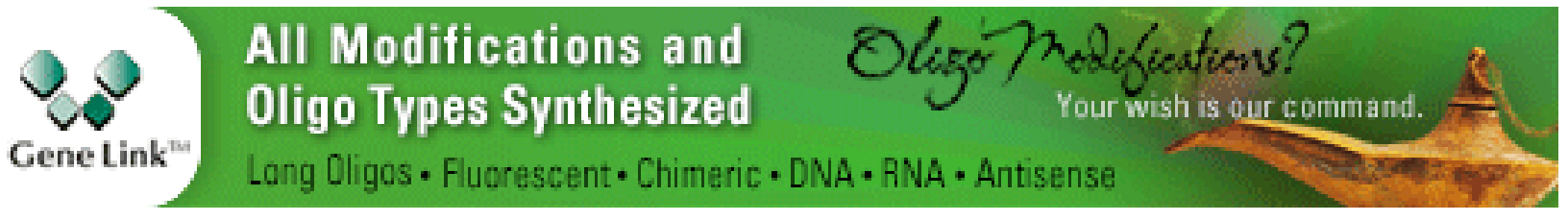

